\title{
TILLERING DYNAMIC AND STRUCTURAL CHARACTERISTICS OF TROPICAL GRASSES UNDER CUTTING MANAGEMENT
}

\author{
DINÂMICA DE PERFILHAMENTO E CARACTERÍSTICAS ESTRUTURAIS DE \\ GRAMÍNEAS TROPICAIS SOB CORTE
}

\section{Alano Albuquerque LUNA ${ }^{1}$; Gelson dos Santos DIFANTE ${ }^{2}$; Denise Baptaglin MONTAGNER ${ }^{3}$; João Virgínio EMERENCIANO NETO ${ }^{4}$; Itânia Maria Medeiros de ARAUJO ${ }^{5}$; Leonardo Santana FERNANDES ${ }^{6}$}

1. Doutorando em Zootecnia, Universidade Federal do Ceará - UFC. alano_luna@ hotmail.com; 2. Programa de Pós-graduação em Produção Animal - PPGPA, Universidade Federal do Rio Grande do Norte - UFRN; 3. Pesquisadora de Embrapa Gado de Corte; 4. Boslsista do PNPD/Capes - PPGPA/UFRN; 5. Doutoranda em Ciência Animal, Universidade Federal do Mato Grosso do Sul; 6. Doutorando em Ciências Climáticas - UFRN.

\begin{abstract}
This paper aimed to evaluate the dynamics of tillering, tiller density and structural characteristics of Brachiaria brizantha, Panicum maximum and Cenchrus ciliaris under a cutting regime. The utilized design was randomized blocks with six treatments (cultivars) and three replications. The evaluations were conducted from May to September 2011, with the data grouped into two periods, rainy season and beginning of the dry season. The greatest tiller population density was observed in the Massai cultivar, averaging 1,019 tillers. $\mathrm{m}^{-2}$. The tiller mortality rate was higher for Mombaça and less for Piatã cultivars. The highest values for forage mass, percentage of leaf blades and relations between green mass:dead mass were observed in Brachiaria brizantha and Panicum maximum cultivars. Panicum and Brachiaria cultivars have shown to be promising for cultivation in the transition areas between the Atlantic Forest and Caatinga biomes in Northeastern Brazil. Cenchrus cultivars are less productive in environments without restriction of abiotic factors.
\end{abstract}

KEYWORDS: Brachiari. Cenchrus. Tiller generation. Morphological composition. Panicum.

\section{INTRODUCTION}

The yield obtained by forage is directly related to the process of photosynthesis, which constitutes in environmental factors being converted into energy, and consequently in the production of biomass. Among tropical grasses used in production systems, the Cenchrus ciliares cultivar shows the greatest resistance to drought. Brachiaria brizantha is the species most widely spread in Brazil, and is the most frequently used grass in pasture production systems. Its adaptation to acid and low fertility soils and high productive capacity (VALLE et al., 2010) ensures its expressiveness. Panicum maximum species is known for its high productivity, nutritious quality and adapting well to different soil and climatic conditions (JANK et al., 2010), so it should be highlighted in research on forage plants.

The basic unit of grass production is the tillers. Tillering is used as a form for plant growth, productivity and increased survival (HODGSON, 1990). The tiller is formed by a sequence of phytomers in which leaf development occurs; tillering originates from axillary buds and root formation. These processes contribute to biomass accumulation, which greatly influences pasture production, as well as its regrowth after defoliation.
The basic unit of grass production is the tillers. The tillering is used as a form for plant growth, productivity and increased survival (Hodgson, 1990). The tiller is formed by a sequence of phytomers in which the development of the leaves occurs, tillering originated from axillary buds, and root formation. These processes contribute to the biomass accumulation, which greatly influence the pasture production, as well as its regrowth after defoliation.

The appearance rate and tiller survival are responsible for population density of plants and determine the portion of vegetative tillers of different ages, which characterize the renovation strength of tillers under grazing (SANTOS et al., 2011).

Thus, forage production occurs with the repetitive emission of leaves and tiller that grows during the year. The population of tillers is dynamic because their life span is a balance between appearance and death, and is extremely dependent on the grazing or cutting regime used.

The objective of this research was to evaluate tillering dynamics, tiller density and structural characteristics of Brachiaria brizantha, Panicum maximum and Cenchrus ciliares under cutting management. 


\section{MATERIAL AND METHODS}

The experiment was conducted in the area of the Study Group on Forage (GEFOR), an Academic Unit Specialized in Agricultural Sciences -at the Federal University of Rio Grande do Norte UFRN in Macaíba, RN. The experimental area is located at $5^{\circ} 53^{\prime} 35.12^{\prime \prime}$ South latitude and $35^{\circ} 21^{\prime}$ 47.03' West longitude and 11 meters above sea level.

The soil of the area is classified as Tipic Quartzipsamment (EMBRAPA, 2006). Soil analyzes were performed on the profiles of $0-20 \mathrm{~cm}$ and $20-40 \mathrm{~cm}$ at the beginning of the experiment (Table 1). According to the soil analysis results, the addition of $\mathrm{K}_{2} \mathrm{O}$ (potassium chloride) was not necessary to meet forage requirements, and it was fertilized with $70 \mathrm{~kg}$ ha ${ }^{-1}$ of $\mathrm{P}_{2} \mathrm{O}_{5}$ (single superphosphate) and $100 \mathrm{~kg} \mathrm{ha}^{-1}$ of nitrogen (ammonium sulfate). Nitrogen was divided into two applications done in May and August. The experimental area was kept permanently free of weeds, and ants were controlled throughout the evaluation period.

Table 1. Soil chemical properties of the experimental field

\begin{tabular}{|c|c|c|c|c|c|c|c|c|c|c|}
\hline $\begin{array}{l}\text { Layer } \\
(\mathrm{cm})\end{array}$ & $\begin{array}{l}\mathrm{P} \\
---- \\
\end{array}$ & $\begin{array}{c}\mathrm{K} \\
\mathrm{ng} \mathrm{dm}\end{array}$ & $\mathrm{Na}$ & $\mathrm{pH}$ & $\begin{array}{c}\mathrm{Ca} \\
---\end{array}$ & $\begin{array}{l}\mathrm{Mg} \\
-\mathrm{cm} \\
\end{array}$ & $\begin{array}{c}\mathrm{Al} \\
\mathrm{n}^{-3}--\end{array}$ & $\begin{array}{l}\mathrm{H}+\mathrm{Al} \\
---\end{array}$ & CEC & $\mathrm{V}(\%)$ \\
\hline $0-10$ & 7.0 & 75.0 & 27.0 & 6.1 & 1.2 & 0.5 & 0.0 & 1.6 & 36.3 & 55.4 \\
\hline $10-20$ & 4.0 & 124.0 & 29.0 & 5.3 & 1.6 & 0.8 & 0.1 & 2.3 & 51.7 & 55.6 \\
\hline
\end{tabular}

CEC, cation exchange capacity; $\mathrm{V}$, percentage of base saturation

The experimental period was from May to September 2011, grouped in two seasons, rainy (May, June, and July) and early dry season (August and September) (Figure.1). The cultivars were sown in January 2011, and the uniformity cut was carried out after 84 days using gardening shears at the height of $0.2 \mathrm{~m}$ from the ground and repeated every
30 days, and always at the same initial height. The climate, according to the Thornthwaite climatic classification (1948), is sub-humid dry with water surplus from May to August. The average historic annual rainfall is $1048 \mathrm{~mm}$ and the annual evapotranspiration potential cumulative average is $1472 \mathrm{~mm}$.

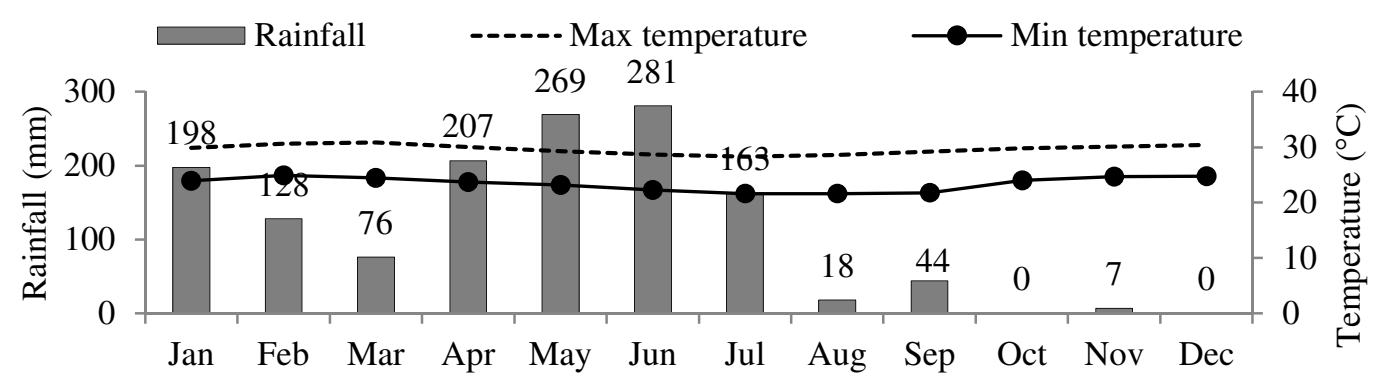

Figure 1. Average monthly rainfall of the experimental area in 2011

Three species of grasses were evaluated: Brachiaria brizantha cvs. Piatã and Xaraés; Panicum maximum cvs. Massai and Mombaça and Cenchrus ciliares cv. Áridus and Biloela. The experiment was conducted on $6.0 \mathrm{~m}^{2}$ plots $(3.0 \mathrm{~m} \mathrm{x}$ $2.0 \mathrm{~m}$ ) with $0.5 \mathrm{~m}$ spacing between plots and $1.0 \mathrm{~m}$ between blocks. Each plot consisted of seven rows of three meters long and $0.33 \mathrm{~m}$ between rows. Harvest was made only for the three central rows, leaving out $0.66 \mathrm{~m}$ from each end.

Tiller population density (TPD) was obtained by the total count of basal tillers contained in a framework of $0.25 \mathrm{~m}^{2}(0.5 \times 0.5 \mathrm{~m})$, randomly cast twice per plot. Tiller counting was performed after each cut, and all data were converted to tillers $\mathrm{m}^{-2}$.

Evaluation of tiller population dynamics was always performed after the cuts. Three frames made of galvanized steel wire were used, measuring $0.0625 \mathrm{~m}^{2}(0.25 \times 0.25 \mathrm{~m})$ and fixed to the ground with metal staples in representative sites of each installment at the beginning of the evaluations. In the first evaluation, all existing tillers within each square were marked with colored wire. All existing marked tillers were counted again at every new assessment, the new tillers were marked with a different color from that in previous markings, and the wires of dead tillers counted and collected. Tillers which had gone missing and those that were 
dry or in an advanced stage of senescence were considered dead.

From this information we calculated the appearance rate, mortality and survival of tillers (ApTR, MoTR, SuTR), expressed as tillers per day: ApTR $=$ tillers developed $\mathrm{x}$ total living tillers in the previous marking ${ }^{-1}$ x 100; MoTR $=$ tillers of the earlier mark - tiller survivors $x$ total living tillers in the previous marking ${ }^{-1} \times 100$; SuTR $=$ tillers of the previous marking living in the current marking $\mathrm{x}$ total living tillers in the previous marking ${ }^{-1} \times 100$. The stability index $\left(\mathrm{P}_{1} \mathrm{P}_{0}^{-1}\right)$ of the number of tillers was calculated according to the methodology described by Bahmani et al. (2003), using the expression: $\mathrm{P}_{1} \mathrm{P}_{0}^{-1}=\operatorname{SuTR}(1+\mathrm{ApTR})$.

Average pasture height was determined by a meter scale graduated in centimeters. Ten readings were conducted per plot and each reading was considered the average height of curvature of the leaves around the scale.

The forage mass was obtained by cutting the useful area at a height of $0.2 \mathrm{~m}$ of soil. The collected samples were identified and weighed to obtain green weight. Two sub-samples were taken, one for determining the total of dry matter, and another for determining the percentage of each morphological component in forage mass, being leaf blade, stem (stem + sheath) and dead material, both dried off by forced ventilation in an oven at $55^{\circ} \mathrm{C}$ for 72 hours to determine the dry weight. The forage volume density was calculated by dividing the forage dry mass per hectare by the canopy height in centimeters $\left(\mathrm{kg} \mathrm{ha}^{-1} . \mathrm{cm}\right.$ of DM).

A randomized block design was used with treatments allocated in split plot with grasses as the plots and the seasons as subplots. Data were subjected to analyses of variance and if significant, Fisher's exact test $(\alpha=5 \%)$, and means were tested by Tukey test at $5 \%$ significance level.
For statistical analysis, the Sisvar program (version 5.6) was used based on the following statistical model: Yijk = $\mu+\mathrm{Ci}+\mathrm{Bj}+\alpha \mathrm{ij}+\mathrm{Ek}+(\mathrm{CE}) \mathrm{ik}+\beta \mathrm{ijk}$, in which: Yijk = value observed for cultivar $I$ in season $k$ in block $j$; $\mu=$ overall average effect; $\mathrm{Ci}=$ effect of cultivar $\mathrm{i}, \mathrm{i}$ $=1,2,3,4,5$ and $6 ; \mathrm{Bj}=$ effect of block $\mathrm{j}, \mathrm{j}=1,2$ and $3 ; \alpha i j=$ random error of cultivar $\mathrm{i}$ in block $\mathrm{j}$; Ek $=$ effect of season $\mathrm{k}, \mathrm{K}=1$ and 2; (CE)ik = interaction of cultivar $\mathrm{i}$ in season $\mathrm{k}$; and eijk = random error associated with cultivar $\mathrm{I}$ in block $\mathrm{j}$ in season $\mathrm{k}$.

\section{RESULTS AND DISCUSSION}

There was no interaction between cultivars and time of year for any of the studied variables $(\mathrm{P}>0.05)$. The highest tiller population density (TPD) was observed in cv. Massai $(\mathrm{P}<0.05)$, while the other cultivars did not differ (Table 2). This feature substantially varies between forage grasses, which can be explained by differences in phenotypic plasticity that grasses present as an adaptation to grazing (NASCIMENTO JR; ADESE, 2004). Possible phenotypic adaptations to the edaphoclimatic conditions of the region may have occurred. Macedo et al. (2010) evaluated morphogenetic and structural characteristics of Mombaça grass with 32 days of regrowth in the northern region and found 751.7 tiller $\mathrm{m}^{-2}$, much higher than the values found in this study. Such disparity among the results may be attributed to the methodology for counting tillers. The authors used a frame of $1.0 \times 0.15 \mathrm{~m}$, whereas the frame used in the present study was $0.5 \times 0.5$; the first format may overestimate the number of tillers if positioned in the sowing area plot rows.

Table 2. Averages of cultivars for tiller population density (TPD), tiller appearance (TApR), mortality (TMoR) and tiller survival (TSuR) rates and stability index (StIn) of tropical forages

\begin{tabular}{|c|c|c|c|c|c|c|c|}
\hline Variable & Áridus & Biloela & Massai & Mombaça & Piatã & Xaraés & $\begin{array}{l}\text { CV } \\
(\%)\end{array}$ \\
\hline TPD (tiller $\mathrm{m}^{-2}$ ) & $260.52 b$ & $270.68 b$ & $1019.52 \mathrm{a}$ & $397.32 b$ & $242.32 b$ & $414.00 \mathrm{~b}$ & 34.79 \\
\hline TApR (tiller day ${ }^{-1}$ ) & $1.07 \mathrm{a}$ & $1.06 \mathrm{a}$ & $1.19 \mathrm{a}$ & $1.29 \mathrm{a}$ & $1.41 \mathrm{a}$ & $1.09 \mathrm{a}$ & 30.15 \\
\hline TMoR(tiller day ${ }^{-1}$ ) & $0.29 \mathrm{ab}$ & $0.26 \mathrm{ab}$ & $0.25 \mathrm{ab}$ & $0.38 \mathrm{a}$ & $0.20 \mathrm{~b}$ & $0.34 \mathrm{ab}$ & 46.05 \\
\hline TSuR (tiller day ${ }^{-1}$ ) & $0.72 \mathrm{ab}$ & $0.74 \mathrm{ab}$ & $0.75 \mathrm{ab}$ & $0.62 b$ & $0.80 \mathrm{a}$ & $0.66 \mathrm{ab}$ & 18.43 \\
\hline StIn & $1.52 \mathrm{a}$ & $1.53 \mathrm{a}$ & $1.66 \mathrm{a}$ & $1.40 \mathrm{a}$ & $1.85 \mathrm{a}$ & $1.39 \mathrm{a}$ & 25.03 \\
\hline
\end{tabular}

Means followed by different letters differ from one another by the Tukey test $(\mathrm{P}<0.05)$ 
The highest TPD observed in the Massai grass compared to the other cultivars can be explained by the cultivar's genetics. According to Jank et al. (2010), the number of tillers formed in the Massai cultivar is greater than any other already known Panicum genus. The great advantage of this variety is plenty of tillers allow their persistence by better efficiency in using productive resources such as water, nutrients and light (LOPES et al., 2011).

No difference was observed among the tested cultivars $(\mathrm{P}>0.05)$ for the tiller appearance rate (Table 2), probably because there were no restrictions put on temperature, light, water or nutrients during the evaluation period. According to Davies (1974), the rate of appearance and tiller population density of a forage grass having no adverse environmental conditions are determined by the number and activity of existing growth points that depend on the leaf appearance rate.

The tiller mortality rate $(\mathrm{TMoR})$ was different between Mombaça and Piatã (Table 2). The tiller survival rate (TSuR) showed opposite behavior to TMoR. The high mortality of tillers in Mombaça cultivation was offset by high tiller appearance rate, which revealed higher renovation, as well as generations with the lowest lifetime, providing a more youthful profile of the population of tillers. These responses become important for the management of cultivars because it can determine shorter resting periods for reestablishment of the sward canopy, which provides for the use of younger forage, hence, better nutritional value.
Moreover, this dynamic is important for the maintenance of the tiller population and especially for the plant's survival in the ecosystem in the medium and long term (MORAIS et al., 2006).

There was no difference between cultivars $(\mathrm{P}>0.05)$, the average stability index observed was 1.56. Values of the stability index less than 1.0 indicate that survival and tillering were not able to compensate for the mortality rates and the population tends to decrease over time (BAHMANI et al., 2003). According to Caminha et al. (2010), this index analyzes the changes in the population of tillers on an integrated basis as it considers appearance rates and tiller survival together, which favors the observation of environmental factors and management effects on the pasture, allowing for better understanding and manipulation of the ecophysiological processes of the plant.

No differences were observed in the TPD between the evaluated periods. During the rainy season, the results showed lower TMoR and larger TSuR $(\mathrm{P}<0.05) \quad($ Table 3$)$, because of the humid conditions (Figure 1). The biggest TApR and TMoR are determined by a compensatory mechanism for maintaining the balance of the population of tillers for the availability of light, water, and the combinations of intensities and cutting frequencies (DIFANTE et al., 2008). The stability index of the tillers during the dry season was lower $(\mathrm{P}<0.05)$, however this was greater than 1.0, suggesting that there was no impairment of plant population during the evaluated period.

Table 3. Averages of cultivar tiller population density (TPD), appearance rate (TApR), mortality (TMoR), tiller survival (TSuR) and stability index (StIn) in two seasons

\begin{tabular}{lccccc}
\hline Season & $\begin{array}{c}\text { TPD } \\
\left(\text { tiller } \mathrm{m}^{-2}\right)\end{array}$ & $\begin{array}{c}\text { TApR } \\
\left.\text { (tiller day }^{-1}\right)\end{array}$ & $\begin{array}{c}\text { TMoR }^{-1} \\
\left(\text { tiller day }^{-1}\right)\end{array}$ & $\begin{array}{c}\text { TSuR } \\
\left(\text { tiller day }^{-1}\right)\end{array}$ & StIn \\
\hline Rainy & $110.14 \mathrm{a}$ & $1.24 \mathrm{a}$ & $0.22 \mathrm{~b}$ & $0.78 \mathrm{a}$ & $1.77 \mathrm{a}$ \\
Early dry & $106.89 \mathrm{a}$ & $1.13 \mathrm{a}$ & $0.35 \mathrm{a}$ & $0.65 \mathrm{~b}$ & $1.34 \mathrm{~b}$ \\
\hline
\end{tabular}

Means followed by different letters differ from one another by the Fischer's exact test $(\mathrm{P}<0.05)$

According to Sbrissia et al. (2010), variations in the appearance rates and tiller mortality show that these processes are related to adaptations plants had because of the growth prevailing conditions, which allows the plants to fully or partially compensate relatively large contrasts, in order to maintain the stability of the plant population in the area. The first generation of tillering dynamics corresponded to the number of tillers on the first counting; the date of onset could not be identified and, therefore, has always been most numerous. A more drastic decrease occurred in the total number of tillers of the first generation in the month of July, when the rainfall began to decline (Figure 1).

The smaller number of tillers was observed in the second and third generation as compared to the first. In the fourth generation, there were a higher number of tillers for Massai and Mombaça cultivars. The smallest emergence of tillers was observed in the fifth generation, possibly due to the effects of drought in September (Figure 1), when the dry season starts.

There was an increase in the population of tillers in Áridus and Biloela cultivars until the month of July, but from the third generation a 
decline in the total number of basal tillers was observed (Figure 2). The Massai cultivar presented many tillers in the first generation, and a drastic decline in the second, which can be explained by the self-thinning law, where the limiting resource (light radiation) determines the adjustment in compensation curve size/density of tillers (SBRISSIA; DA SILVA, 2008), and from the third generation it grew considerably. In Mombaça grass, tiller population gradually increased in each generation.
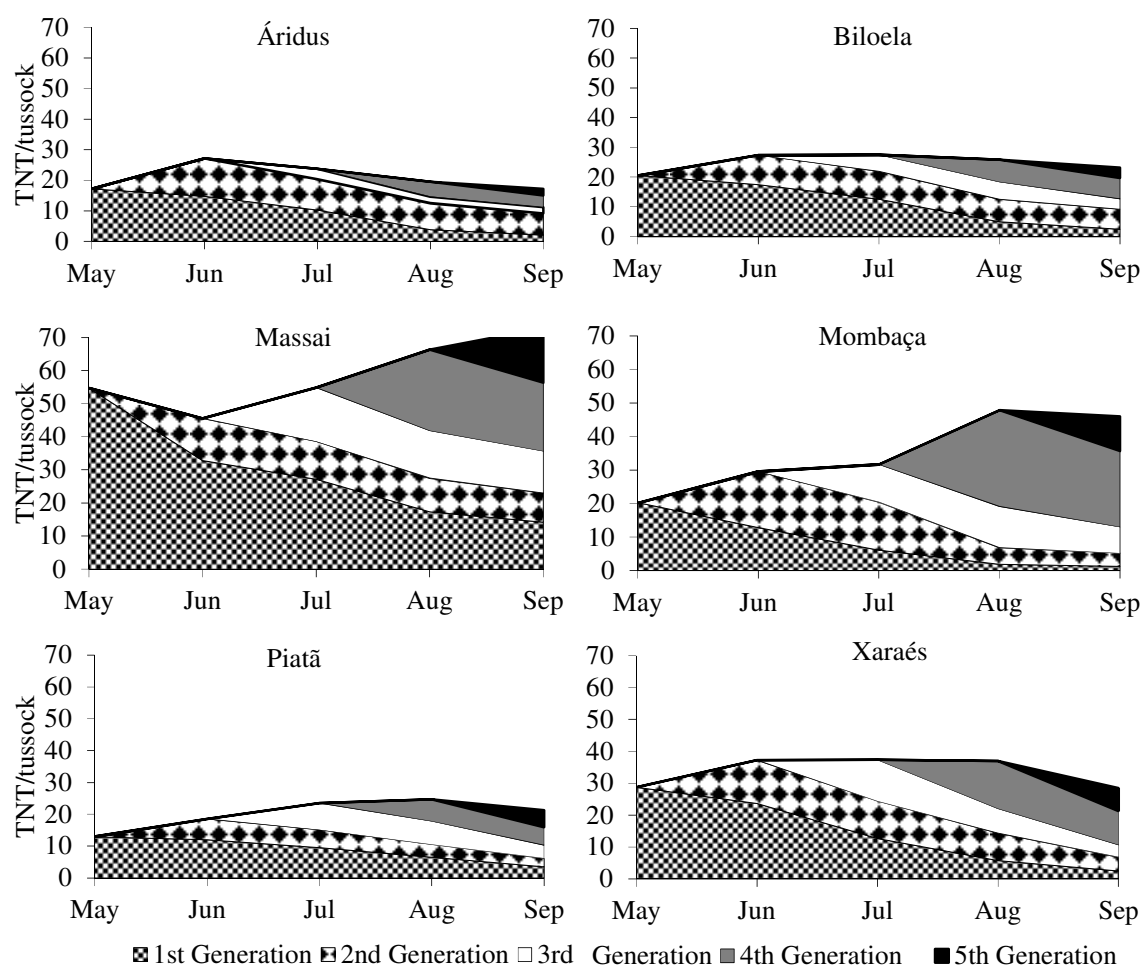

Figure 2. Tiller population dynamics (total number of tillers (TNT)/tussock) of six tropical forages in cutting regime

The greatest pasture height values were recorded in Mombaça and Xaraés cultivars $(\mathrm{P}<0.05)$ and did not differ from Piatã cultivar (Table 4). The Panicum maximum and Brachiaria brizantha species are taller, a fact noted by Silveira et al. (2010) when they compared forage cultivar groups of the Panicum and Brachiaria genus. Cutting and grazing height is widely used as a reliable management criterion for controlling and monitoring the regrowth process (CARNEVALLI et al., 2006). According to Gomide et al. (2006), it is important to consider for erect grasses, particularly in tropical climates, a reduction in the stem elongation process can be used as a management tool.

Table 4. Cultivar averages $s$ for structural variables of canopy cutting

\begin{tabular}{lccccccc}
\hline Variable & Áridus & Biloela & Massai & Mombaça & Piatã & Xaraés & CV(\%) \\
\hline CH & $37.09 \mathrm{~d}$ & $39.05 \mathrm{~cd}$ & $43.87 \mathrm{bc}$ & $52.24 \mathrm{a}$ & $47.66 \mathrm{ab}$ & $52.24 \mathrm{a}$ & 11.86 \\
FDM & $742.87 \mathrm{c}$ & $936.35 \mathrm{bc}$ & $1684.58 \mathrm{a}$ & $1347.60 \mathrm{ab}$ & $1540.31 \mathrm{ab}$ & $1753.85 \mathrm{a}$ & 19.07 \\
VD & $20.03 \mathrm{c}$ & $23.98 \mathrm{bc}$ & $38.40 \mathrm{a}$ & $25.80 \mathrm{bc}$ & $32.32 \mathrm{ab}$ & $33.57 \mathrm{ab}$ & 17.33 \\
PLB & $40.57 \mathrm{c}$ & $47.73 \mathrm{c}$ & $84.18 \mathrm{a}$ & $83.60 \mathrm{a}$ & $65.40 \mathrm{~b}$ & $76.35 \mathrm{a}$ & 9.85 \\
SP & $35.93 \mathrm{a}$ & $34.31 \mathrm{ab}$ & $6.56 \mathrm{~d}$ & $5.16 \mathrm{~d}$ & $25.10 \mathrm{bc}$ & $15.86 \mathrm{c}$ & 16.15 \\
DMP & $23.50 \mathrm{a}$ & $17.96 \mathrm{a}$ & $9.26 \mathrm{~b}$ & $11.24 \mathrm{~b}$ & $9.50 \mathrm{~b}$ & $7.79 \mathrm{~b}$ & 16.18 \\
GM DM $^{-1}$ & $3.25 \mathrm{c}$ & $4.57 \mathrm{bc}$ & $9.80 \mathrm{a}$ & $7.90 \mathrm{ab}$ & $9.53 \mathrm{a}$ & $11.84 \mathrm{a}$ & 17.81
\end{tabular}

$\mathrm{CH}$ (canopy height, $\mathrm{cm}$ ), FDM (forage dry matter, $\mathrm{kg} \mathrm{ha}^{-1}$ ), VD (volumetric density of forage $\mathrm{kg} \mathrm{cm}^{-1}$.ha), PLB (percentage of leaf blade, $\%$ of FDM), SP (stem percentage, $\%$ of FM), DMP (dead material percentage, $\%$ of FDM), GM DM ${ }^{-1}$ (ratio between green mass and dead material). Means followed by different small letters on the line differ by Tukey test $(\mathrm{P}<0.05)$ 
The amount of forage dry mass (FDM) was higher in Xaraés and Massai cultivars (Table 4). This can be explained by the high population density of tillers from these cultivars (Table 2) and the association between tiller density and forage production (WADE, 1979).

The higher forage volumetric density (VD) was obtained in Massai cultivar and the lowest in Áridus cultivar (Table 4). The high VD observed in Massai cultivar can also be attributed to high density of tillers (Table 2), since high FDM median time was observed. On the other hand, the result of Áridus cultivar can be attributed to their physiological stage (reproductive), since according to Bauer et al. (2011), as the canopy becomes reproductive, the density and leaf:stem ratio begins to decrease and the amount of dead material increases. In this condition, grazing animals tend to be more selective and hence a decline in consumption per bite is expected.

The percentage of leaf blades (PLB) in FDM differed between cultivars $(\mathrm{P}<0.05)$. The highest values were obtained in the Massai, Mombaça and Xaraés cultivars, being lower for Áridus and Biloela cultivars and intermediate for Piatã cultivar (Table 4). According to Davies (1974), the potential for tillering is determined by the number and activity of existing growth points that depend on the leaf appearance rate; therefore the Brachiaria and Panicum cultivars had the highest tiller population density and percentages of leaf blades.

The stem percentages (SP) differed between cultivars $(\mathrm{P}<0.05)$. The lowest values were found for the cultivars of the Panicum genus, followed by Brachiaria cultivars (Table 4). As there was no change in cutting intervals between grasses, this result was attributed to stem elongation rates described by Luna et al. (2014) for these cultivars, where the higher the stem elongation rate, the higher the stem participation in forage mass.

The dead material percentages (DMP) differed between cultivars $(\mathrm{P}<0.05)$. The lowest values were found for the cultivars of Panicum and Brachiaria (Table 4). This result is a consequence of senescence rates of each cultivar, with the highest rates were obtained in Cenchrus cultivars (LUNA et al., 2014).

The difference in the morphological composition of Áridus and Biloela cultivars in relation to the others can be explained by the early flourishing of these plants, as the plants were already in the reproductive stage at the time of cutting. In this process, there is greater stem elongation for issuing inflorescences and redistribution of nutrients from leaves to seeds, with consequent senescence of some of the tiller leaf blades. Thus, an increase in the percentage of stem and dead material and reduction in leaf blades can be observed in forage mass composition.

The observed percentage of dead material is satisfactory and shows that the interval between cuts was not long, when the duration of the leaf life is shorter than the adopted rest period, and the first sheet expanded after defoliation thus entering the senescence process even during the regrowth period, which results in high pasture senescence rates (CASAGRANDE et al., 2010). According to Difante et al. (2011), pastures with high production of stem and senescent material harm energy seizure and forage handling, affecting consumption by grazing animals and decreases the efficiency ratios in using produced forage.

There were differences among cultivars in living/dead material relationship (Table 4). The highest values were obtained in cultivars of the genus Brachiaria and Panicum. The relation of living/dead material is related to the production of dry matter, which in addition to being influenced by sward, is also influenced by the plants' genetic potential and the intensity of environmental conditions which favor or do not favor growth.

The canopy height varied between seasons of the year (Table 5). The greatest height was found during the rainy season with $53.7 \mathrm{~cm}$. At the beginning of the drought, the canopy height was $37.0 \mathrm{~cm}$. At the beginning of the dry period there was a reduction of $31.2 \%$ in canopy height due to water shortage, limiting growth and stimulating the senescence process. According to Taiz and Zeiger (2009), for plants with $\mathrm{C}_{4}$ metabolism such as species of the genus Panicum, Brachiaria and Cenchrus, approximately $300 \mathrm{~g}$ of water are absorbed by the roots for each produced gram of organic matter, but $95 \%$ is lost by transpiration process and the remainder is used in plant growth and metabolism. This statement supports what was observed during the experimental period, because to the extent that water availability decreased (Figure 1), forage accumulation also decreased.

The forage dry mass varied between seasons of the year (Table 5). The greatest FDM was found in the rainy season, and was lower at the beginning of the drought. The seasonality in forage production is a phenomenon that occurs in most tropical forages, being mainly determined by limitations of light, water availability and temperature (MALDONADO et al., 1997). In the Northeast of Brazil, the most critical factor is the availability of water (Figure 1). Ribeiro et al., (2009) observed that 
irrigation increased the dry matter production of Mombaça grass and Napier grass. Even in nonirrigated conditions, Mombaça decreased about $30 \%$ in the production of dry matter, showing that water directly influences the production of dry matter of grasses.

Table 5. Means of canopy structural variables in two seasons of the year

\begin{tabular}{lccccccc}
\hline Season & CH & FM & VD & PLB & SP & DMP & GM DM $^{-1}$ \\
\hline Rainy & $53.75 \mathrm{a}$ & $1910.10 \mathrm{a}$ & $35.54 \mathrm{a}$ & $64.57 \mathrm{~b}$ & $23.70 \mathrm{a}$ & $11.72 \mathrm{a}$ & $7.53 \mathrm{a}$ \\
Early dry & $36.96 \mathrm{~b}$ & $759.33 \mathrm{~b}$ & $20.54 \mathrm{~b}$ & $69.65 \mathrm{a}$ & $16.17 \mathrm{~b}$ & $14.18 \mathrm{a}$ & $6.05 \mathrm{a}$ \\
\hline
\end{tabular}

CH (canopy height, cm), FM (forage dry matter, kg.ha ${ }^{-1}$ ), VD (volumetric density of forage kg.cm ${ }^{-1}$.ha), PLB (percentage of leaf blade, $\%$ of FM), SP (stem percentage, \% of FM), DMP (dead material percentage, \% of FM), GM.DM ${ }^{-1}$ (ratio between green mass and dead material). Means followed by different small letters in the column differ by Fisher's exact test $(\mathrm{P}<0.05)$

The volumetric density of forages (VD) varies between seasons of the year (Table 5). The highest value for VD was during the rainy season, and lower at the beginning of the drought. These values are related to the fact that volumetric density was determined by FDM, and was also influenced by the lower height observed in pastures at the beginning of the drought. Ribeiro et al. (2009) reported that irrigation increased the volumetric density in both Napier and Mombaça forages in the dry season, showing that water also influences the volumetric density of plants.

The percentage of leaf blades (PLB) and stem (SP) differed between the seasons of the year $(\mathrm{P}<0.05)$. The highest percentage of the fraction of leaf blades was observed at the beginning of the dry season (Table 5) due to the low percentage of stem fraction in the amount of FDM. To evaluate the effect of irrigation, Magalhães et al. (2013) noted that if the water layer was lower, there was a reduction in stem elongation rate, confirming that the reduced availability of water in the soil promotes a reduction in stem elongation due to a lower flow of tissues when compared to the system with higher water availability, as this is a limiting factor for plant growth. The dead material proportion (DMP) and relation of living/dead material $\left(\mathrm{GM} \mathrm{DM}^{-1}\right)$ did not differ between the seasons of the year $(\mathrm{P}>0.05)$.

Adaptation of cultivars to the conditions of the study area based on the values of morphological components may be inferenced, which are equivalent or surpass the annual average of these cultivars in other regions. Euclides et al. (2008), in working with. Xaraés and Piatã cultivars in the Midwest under grazing obtained values close to those demonstrated in this work. Emerenciano Neto et al. (2013) evaluated Brachiaria and Panicum cultivars under grazing and also found high production capacity from these grasses in northeastern Brazil.

\section{CONCLUSION}

Panicum and Brachiaria cultivars have shown to be promising for cultivation in the transition areas between the Atlantic Forest and Caatinga biomes in northeast Brazil, as the tiller population density of these cultivars results in higher forage production. Cenchrus cultivars are less productive in environments without any restriction of abiotic factors when compared to other cultivars.

\section{ACKNOWLEDGEMENTS}

To CNPq and CAPES for the financial support on the experiment development and the scholarship to the first writer. To the group of forage studies-GEFOR (UFRN), for their support in the research.

RESUMO: Objetivou-se avaliar a dinâmica de perfilhamento, a densidade populacional de perfilhos e as características estruturais de cultivares de Brachiaria brizantha, Panicum maximum e Cenchrus ciliaris em regime de corte. O delineamento utilizado foi em blocos ao acaso com seis tratamentos (cultivares) e três repetições. As avaliações foram realizadas de maio a setembro de 2011, sendo os dados agrupados em dois períodos, águas e início da seca. A maior densidade populacional de perfilhos foi observada na cultivar Massai com média de 1019 perfilhos $/ \mathrm{m}^{2}$. A taxa de mortalidade de perfilhos foi maior na cultivar Mombaça e menor na Piatã. Os maiores valores para massa de forragem, percentual de lâminas foliares e relações entre massa verde:massa morta foram observados nas cultivares de Brachiaria brizantha e Panicum maximum. As cultivares de Panicum e Brachiaria se mostraram promissoras à utilização em áreas de transição entre os biomas de Mata Atlântica e Caatinga na Região Nordeste do Brasil. As cultivares de Cenchrus são menos produtivas em ambientes sem restrição de fatores abióticos. 
PALAVRAS-CHAVE: Brachiaria. Cenchrus. Composição morfológica. Gerações de perfilhos. Panicum.

\section{REFERENCES}

BAHMANI, I.; THOM, E. R.; MATTHEW, C.; HOOPER, R. J.; LEMAIRE, G. Tiller dynamics of perennial ryegrass cultivars derived from different New Zealand ecotypes: effects of cultivar, season, nitrogen fertilizer, and irrigation. Australian Journal of Agricultural Research, v. 54, n. 8, p. 803-817, aug. 2003. http://dx.doi.org/10.1071/AR02135

BAUER, M. O.; PACHECO, L. P. A.; CHICHORRO, J. F.; VASCONCELOS, L. V.; PEREIRA, D. F. C. Produção e características estruturais de cinco forrageiras do gênero Brachiaria sob intensidades de cortes intermitentes. Ciência Animal Brasileira, Goiânia, v. 12, n. 1, p. 17-25, jan./mar. 2011.

http://dx.doi.org/10.5216/cab.v12i1.4817

CAMINHA, F. O.; SILVA, S. C.; PAIVA, A. J.; PEREIRA, L. E. T.; MESQUITA, P.; GUARDA, V. D. Estabilidade da população de perfilhos de capim-marandu sob lotação contínua e adubação nitrogenada. Pesquisa Agropecuária Brasileira, Brasília, v. 45, n. 2, p. 213-220, feb. 2010.

http://dx.doi.org/10.1590/S0100-204X2010000200013

CARNEVAlLI, R. A.; DA SILVA, S. C.; BUENO, A. A. O.; UEBELE, M. C.; BUENO, F. O.; HODGSON, J.; SILVA, G. N.; MORAIS, J. P. G. Herbage production and grazin glosses in Panicum maximum cv. Mombaça under four grazing managements. Tropical Grasslands, Brisbane, v. 40, p. 165-176, 2006.

CASAGRANDE, D.; RUGGIERI, A. C.; JANUSCKIEWICZ, E. R.; GOMIDE, J. A.; REIS, R. A.; VALENTE, A. L. S. Características morfogênicas e estruturais do capim-marandu manejado sob pastejo intermitente com diferentes ofertas de forragem. Revista Brasileira de Zootecnia, Viçosa, v. 39, n. 10, p. 2108-2115, out. 2010.

DAVIES, A. Leaf tissue remaining after cutting and regrowth in perennial ryegrass. Journal Agriculture Science, Cambridge, v. 82, n. 1, p. 165-172, 1974. http://dx.doi.org/10.1017/S0021859600050334

DIFANTE, G. S. NASCIMENTO JÚNIOR, D.; SILVA, S. C.; EUCLIDES, V. P. B.; ZANINE, A. M.; ADESE, B. Dinâmica do perfilhamento do capim-marandu cultivado em duas alturas e três intervalos de corte. Revista Brasileira de Zootecnia, Viçosa, v. 37, n. 2, p. 189-196, feb. 2008.

DIFANTE, G. S. NASCIMENTO JÚNIOR, D.; SILVA, S. C.; EUCLIDES, V. P. B.; MONTAGNER, D. B.; SILVEIRA, M. C. T.; PENA, K. S. Características morfogênicas e estruturais do capim-marandu submetido a combinações de alturas e intervalos de corte. Revista Brasileira de Zootecnia, Viçosa, v. 40, n. 5, p. 955-963, may. 2011.

Empresa Brasileira de Pesquisa Agropecuária - EMBRAPA. Sistema brasileiro de classificação de solos. 2.ed. Rio de Janeiro, 2006. 306p.

EMERENCIANO NETO, J. V.; DIFANTE, G. S.; MONTAGNER, D. B.; BEZERRA, M. G. S.; GALVÃO, R. C. P.; VASCONCELOS, R. I. G. Características estruturais do dossel e acúmulo de forragem em gramíneas tropicais, sob lotação intermitente e pastejada por ovinos. Bioscience Journal, Uberlândia, v. 29, n. 4, p. 962973, jul./aug. 2013.

EUCLIDES, V. P. B.; MACEDO, M. C. M.; VALLE, C. B.; BARBOSA, R. A.; GONÇALVES, W. V. Produção de forragem e características da estrutura do dossel de cultivares de Brachiaria brizantha sob pastejo. Pesquisa Agropecuária Brasileira, Brasília, v. 43, n. 12, p. 1805-1812, dec. 2008. http://dx.doi.org/10.1590/S0100-204X2008001200023 
GOMIDE, C. A. M.; GOMIDE, J. A.; PACIULLO, D. S. C. Morfogênese como ferramenta para o manejo de Pastagens. In: SIMPÓSIOS DA 43 ${ }^{\text {a }}$ REUNIÃO ANUAL DA SBZ. Annals... João Pessoa: Sociedade Brasileira de Zootecnia, 2006.

HODGSON, J. Grazing Management: Science into practice. New York: John Wiley \&Sons.p. 203, 1990.

JANK, L.; MARTUSCELLO, J. A.; EUCLIDES, V. P. B.; VALLE, C.B.; RESENDE, R. M. S. Panicum maximum. In: FONSECA, D. M.; MARTUSCELLO, J. A. (Edt.). Plantas Forrageiras. Viçosa, MG. 2010. cap. 5 .

LOPES, M. N.; CÂNDIDO, M. J. D.; POMPEU, R. C. F. F.; SILVA, R. G.; BEZERRA, F. M. L. Componentes estruturais do resíduo pós-corte em capim-massai adubado com cinco doses de nitrogênio.

Revista Ciência Agronômica, Fortaleza, v. 42, n. 2, p. 518-525, apr./jun. 2011.

http://dx.doi.org/10.1590/S1806-66902011000200035

LUNA, A. A.; DIFANTE, G. S.; MONTAGNER, D. B.; EMERENCIANO NETO, D. B.; ARAÚJO, I. M. M.; OLIVEIRA, L. E. C. Características morfogênicas e acúmulo de forragem de gramíneas forrageiras, sob corte.

Bioscience Journal, Uberlândia, v. 30, n. 6, p. 1803-1810, nov./dec. 2014.

MACEDO, C. H. O.; ALEXANDRINO, E.; JAKELAITIS, A.; VAZ, R. G. M. V.; REIS, R. H. P.; VENDRUSCULO, J. Características agronômicas, morfogênicas e estruturais do capim Panicum maximum cv. Mombaça sob desfolhação intermitente. Revista Brasileira de Saúde e Produção Animal, Salvador, v. 11, n. 4, p. 941-952, oct./dec. 2010.

MAGAlHAES, J. A.; CARNEIRO, M. S. S.; ANDRADE, A. C.; PEREIRA, E. S.; ANDRADE, A. P.; BAKKE, O. A.; RODRIGUES, B. H. N.; MOCHEL FILHO, W. J. E.; COSTA, N. L. Características morfogênicas e estruturais do capim-andropogonsob irrigação e adubação. Semina: Ciências Agrárias, Londrina, v. 34, n. 5, p. 2427-2436, sep./oct. 2013. http://dx.doi.org/10.5433/1679-0359.2013v34n5p2427

MALDONADO, H.; DAHER, F. R.; PEREIRA, A. V. Efeito da irrigação na produção de matéria seca do capim elefante (Pennisetum purpureum) em Campos dos Goytacazes, RJ. In: REUNIÃO ANUAL DA SOCIEDADE BRASILEIRA DE ZOOTECNIA, 34., Juiz de Fora, 1997. Annals... Juiz de Fora: SBZ, 1997.

MORAIS, R. V. ET AL FONSECA, D. M.; NASCIMENTO JÚNIOR, D.; RIBEIRO JUNIOR, J. I.; FAGUNDES, J. L.; MOREIRA, L. M.; MISTURA, C.; MARTUSCELLO, J. A. Demografia de perfilhos basilares em pastagem de Brachiaria decumbens adubada com nitrogênio. Revista Brasileira de Zootecnia, Viçosa, v. 35, n. 2, p. 380-388, mar./apr. 2006.

NASCIMENTO JR., D.; ADESE, B. Acúmulo de biomassa na pastagem. In: SIMPÓSIO SOBRE MANEJO ESTRATÉGICO DA PASTAGEM, 2., 2004, Viçosa, MG. Annals... Viçosa, MG: Universidade Federal de Viçosa, 2004. p. 289-330.

RIBEIRO, E. G.; FONTES, C. A. A.; PALIERAQUI, J. G. B.; CÓSER, A. C.; MARTINS, C. E.; SILVA, R. C. Influência da irrigação, nas épocas seca e chuvosa, na produção e composição química dos capins napier e mombaça em sistema de lotação intermitente. Revista Brasileira Zootecnia, Viçosa, v. 38, n. 8, p. 1432-1442, aug. 2009.

SANTOS, M. C. S.; LIRA, M. A.; TABOSA, J. N.; MELLO, A. C. L.; SANTOS, M. V. F. Comportamento de clones de Pennisetum submetidos a períodos de restrição hídrica controlada. Archivos de Zootecnia, Córdoba, v. 60 , n. 229 , p. 31-39, mar. 2011. http://dx.doi.org/10.4321/s0004-05922011000100004

SANTOS, M. E. R.; GOMES, V. M.; FONSECA, D. M.; ALBINO, R. L.; SILVA, S. P.; SANTOS, A. L. Número de perfilhos do capim-braquiária em regime de lotação contínua. Acta Scientiarum Animal Sciences, Maringá, v. 33, n. 1, p. 1-7, oct./dec. 2011. 
SBRISSIA, A. F.; DA SILVA, S. C. Compensação tamanho/densidade populacional de perfilhos em pastos de capim-marandu. Revista Brasileira de Zootecnia, Viçosa, v. 37, n. 1, p. 35-47, jan. 2008.

http://dx.doi.org/10.1007/s11258-009-9647-7

SBRISSIA , A. F.; SILVA, S. C.; SARMENTO, D. O. L.; MOLAN, L. K.; ANDRADE, F. M. E.;

GONÇALVES, A. C.; LUPINACCI, A. V. Tillering dynamics in palisadegrass swards continuously stocked by cattle. Plant Ecology, v. 206, n. 2, p. 349-359, jul. 2010.

SILVEIRA, M. C. T.; NASCIMENTO JÚNIOR, D.; SILVA, S. C.; EUCLIDES, V. P. B.; MONTAGNER, D. B.; SBRISSIA, A. F.; RODRIGUES, C. S.; SOUSA, B. M. L.; PENA, K. S.; VILELA, H. H. Morphogenetic and structural comparative characterization of tropical forage grass cultivars under free growth.

ScientiaAgricola, Piracicaba, v. 67, n. 2, p. 136-142, mar./apr. 2010. http://dx.doi.org/10.1590/s010390162010000200002

TAIZ, L.; ZEIGER, E. Fisiologia Vegetal. Porto Alegre: Artmed, 4.ed., 2009. 81.

VALLE, C. B.; MACEDO, M. C. M.; EUCLIDES, V. P. B.; JANK, L.; RESENDE, R. M. Gênero Brachiaria. In: FONSECA, D. M.; MARTUSCELLO, J. A. Plantas Forrageiras. Viçosa, MG. 2010.cap. 2.

WADE, M. H. Leaf and tiller dynamics in grazed swards.Reading, 1979.215p. Thesis (Ph. D.) - University of Reading.

THORNTHWAITE, C. W. An approach toward a rational classification of climate. Geographical Review, v. 38, p. 55-94, 1948. http://dx.doi.org/10.2307/210739 